\title{
RESEARCH ON THE PRODUCTION OF CZECH SOUND RECORDINGS TO I946 FOCUSING ON THE GRAMOPHONE COMPANY ESTA ${ }^{132}$
}

Filip Šir, Institute of Information Studies and Librarianship at the Faculty of Arts of Charles University in Prague, Moravian Library in Brno, Czech Republic

\section{Abstract}

The study brings the partial results of the research undertaken within the framework of the project Internal Grants of the Faculty of Arts of Charles University. The research deals with the Czech production of sound recordings and it is focused on the gramophone record company ESTA up to 1946 in Czechoslovakia. A brief summary of the evolution of gramophone records is followed by an introduction of the first Czechoslovak gramophone company ESTA and its production. Methodologically, the study relies on a physical survey of the phonograph records in selected collections in our country and abroad and on the historical bibliographic records or databases of selected institutions in the Czech Republic. The aim of the research is to collect bibliographic information about the production of gramophone records in our territory to 1946 and, in cooperation with the Moravian Library in Brno, finally to make the data gradually accessible in the Virtual National Phonotheque database.

Keywords: sound recording, gramophone company ESTA, study, databases, bibliographic data

\section{Introduction}

Internal grants of The Faculty of Arts of Charles University enable the emergence of interesting projects in the field with the possibility of scientific activities which would under normal conditions hardly occur. Support and motivation for students is through this grant very welcome and implements realization of previously approved projects. In cooperation with the Director of the Institute of Information Studies and Librarianship, PhDr. Barbora Drobíková, Ph.D., we prepared a project named "Research on the Production of Czech Sound Recordings to 1946 Focusing on the Gramophone Company ESTA" at the end of 2013. The project was successfully approved.

The decision to start with this project was to a large extent influenced by my participation in the projects closely related to the issue of gramophone records. Fortunately, I had an opportunity to address these issues through my work experience in the Moravian Library in Brno. In the first place, I need to say that this topic is nowadays very neglected, almost forgotten. Given that audio recordings have been with us already for more than 130 years, we also need to consider that this medium was used during the 19th and 20th century to preserve the memories of the nation. Therefore, we are talking about documents that are as important as printed documents, i.e., an indispensable value for some professionals. An important part of a country's cultural heritage is formed by a comprehensive database of discography records covering all commercially published audio documents related to that country. This has not been established in any form, and thus we are losing all the important, interesting and rare records from the 19th and 20th century forever. In many countries of the world, an exhaustive discography of audio recordings has already been published, including the history and development of the sound recording industry companies in the countries concerned. However, when we focus on a specific part of the audio documents (recordings published in the first half of the 20th century on the territory of Czechoslovakia), we encounter no such thing as databases by distinguished foreign publishers mentioned above.

Because of this situation, it was our intention to select the first Czechoslovak record label ESTA, which operated on the territory of Czechoslovakia from 1930 until 1946. As there is

132 This article was originally published in Prolnflow journal: peer-reviewed journal focused on the field of information sciences, I/2014. http://pro.inflow.cz 
no discography processed into any form of a comprehensive database, we decided to create it. It is needless to say that the work could not be carried out without the surveys in memory institutions. Furthermore, there is also the need of other research of the old reservation catalogues and the necessary assembling of the data found in the form of bibliographic records, and it is clear that it would not be possible to complete this work without the help of private collectors and colleagues from the field, but most importantly, without the assistance of the various institutions. Building a database of this historically important gramophone company (including contents of the recordings, artists, and artistic value) allows us to preserve this cultural heritage for the next generations.

\section{The Information Research}

There were many collectors in Czechoslovakia and in the Czech Republic during the 20th century. Unfortunately, they were the only professionals and experts early in the history of the gramophone records in our country and, as time passed, any efforts to handle this issue vanished. There are only a handful of those who are dealing with this issue today. We can find very little information about the period of time before 1946 in public resources. Since the largest part of the discography was carried in the catalogues of the gramophone company, it was not preserved given its status of the so-called grey literature. There can be found two documents ${ }^{133}$ (catalogues) in the Union Catalogue of the Czech Republic which contain records of published albums by Czechoslovak brands Esta, Ultraphon, and Supraphon from 1930 until 1945. ${ }^{134}$ Unfortunately, we have found that they are incomplete; with entire series, catalogue, and matrix numbers missing. Further inquiry revealed that the documents have been modified in accordance with the ideology of the time (e.g., missing classics of the Czech music scene and forbidden authors).

Mr. Gabriel Gössel is a private collector who studies and deals with the issues of the gramophone industry in Czechoslovakia. His two books on the history of sound recording represent the most complete work covering the beginnings of the gramophone industry in the 19th and 20th century on our territory. ${ }^{135}$ The first time we encounter a more comprehensive text about the history of the ESTA company is in the publication "Fonogram 2 -Výlety k počátkủm historie záznamu zvuku."'136 The text is focused on the beginnings of this company and then introduces us to the production and promoting of famous artists. It also helps us to understand the marking system used for discs, i.e. the catalogue numbers located on the labels. A very important part of this publication is the dating of Czech repertoire recordings based on the catalogue numbers of the disc, which became a central element of the survey itself.

Regarding the terms of searching the databases of selected institutions during the initial survey, we have found only 70,000 records in the Union Catalogue of the Czech Republic. The oldest of the audio documents, a vinyl record, comes from the collections of the Central Library of the Faculty of Arts of the Masaryk University and was published in 1952.137 Nevertheless, searching the catalogue of the National Library of the Czech Republic returns no records ear-

133 Československá hudba na gramofonových deskách: Ultraphon, Esta, Supraphon. Vyd. I. Praha: Gramofonové závody, $1947.61 \mathrm{~s}$.

134 Celkový katalog gramofonových desek: Supraphon, Ultraphon, Esta.V Praze: Gramofonové závody, 1948. I sv. (přeruš. str.).

I 35 GÖSSEL, Gabriel. Fonogram. Praktický průvodce historií záznamu zvuku. I. vyd. V Praze: Radioservis, 200 I. 229 s. ISBN 80-86212-19-X.

I 36 GÖSSEL, Gabriel. Fonogram. 2, Výlety k počátkům historie záznamu zvuku. I. vyd. Praha: Radioservis, 2006. 536 s. ISBN 80-862I 2-44-0.

137 NKC: Online katalog Národní knihovny České republiky [online databáze]. Praha: Národní knihovna České republiky, 2009- . Dostupná z: http://aleph.nkp.cz/F/DRP95MP9R68B2RGRUNT23PH2JMG8J8SX3R8YD83KRJ528DVCIH$36|6|$ ?func=file\&file_name=find-b\&local_base=NKC 
lier than 1981. ${ }^{138}$ When searching the catalogue of the Czech Museum of Music, we got the total number of 3,379 sound recordings published from 1900 to the present time. Unfortunately, records containing only the information about the title, artist, and the call number are not sufficient. ${ }^{139}$ The total number from the online catalogue also does not match the total number of audio documents found in the archives of the Museum - there are tens of thousands of copies. Therefore, we needed to visit the catalogues in person.

\section{History of the Gramophone Company ESTA}

There were two companies in the early 1930s in Czechoslovakia, which successfully created a market for various genres and different approaches to music. This state of affairs lasted for a long time until 1946. These companies became the pride of the Czechoslovak gramophone industry and in a very strong competitive struggle with other labels were able to work together. The first one was Ultraphon and the second one was ESTA — the first purely Czechoslovak record label in our territory.

The first company in Czechoslovakia to establish a production of gramophone records was mentioned in the press in the mid-1930s. It should be Foresta, a company engaged in the lumber trade. Apparently, a part of the name Foresta was used for the newly formed records company and the image of a flying heron was added as a label symbol. ${ }^{140}$

It is noteworthy that the company issued flexible celluloid records back in the 1930s. According to some sources, there were more than 220 records under the catalogue numbers 100-213. There were also reprints from matrixes of the German record labels Kalliope, Artiphon, and Vox. The repertoire was the so-called "swept shelves"; thus recordings were a vast medley ranging from Hebrew via US opera to dance orchestras and Czech folk. However, it also contained some rare Czech recordings of the famous R. A. Dvorský. Nonetheless, they fell out of fashion very quickly and at the end of 1931 the company decided to switch to the classic shellac records. As a matter of fact, there was no other option because shellac became the standard for most of the European as well as worldwide production.141

When browsing historical catalogues, we can see that the composition of the repertoire until 1939 was focused mostly on folklore. What is very interesting is the gradual acquisition of funding based on publishing of customized advertising records. One of the examples is the contract with "Československá obec sokolská [Czechoslovak gymnastics organization Sokol]". Under the contract, production of vinyl records that musically accompanied physical exercises performed at "IX. všesokolský slet [9th Sokol gathering]" was commissioned. These records can be found on matrix numbers 2617-2629.

The quality of the recordings was comparable to recordings made by publishers worldwide and at the beginning of the German occupation emphasis was placed on recording of classical music, especially by Czech composers, which was also emphasized in the export to Poland, Hungary, Bulgaria, or Austria. After World War II started, the record label ESTA faced a common problem with the lack of high-quality materials for manufacture. Germany was, among other things, cut off from the sources of shellac, which was a valuable and necessary raw material for the production of gramophone records. Especially in the years 1940-1942 ESTA's records of popular music very often suffered from poor quality, when the recording itself

138 SKC: Souborný katalog České republiky (CASLIN) [online databáze]. Praha: Národní knihovna České republiky, 2009- . Dostupná z: http://aleph.nkp.cz/F/GSKUBINV I597AV99AEC4P8PIUIQRQRHASMIFK6EPJJBG2CJ I FL03030 ?func $=$ file\&file_name $=$ find $-b \& l o c a l \_b a s e=S K C$

139 České muzeum hudby on-line katalog [online databáze]. Praha: Národní muzem. České muzeum hudby, [2014-] . Dostupná z: http://opac.nm.cz:8080/opaccmh/

I 40 Gramotechnika: první oficielní odborný list Svazu pro průmysl a obchod s gramofony v ČSR. Praha: Svaz průmyslu a obchodu gramofony, hudebními nástroji a jich príslušenstvím, 1929-1935.

|4| Až kometa šlehne nás: z historie zvukového záznamu. Praha: Galery, 2003. 9 | s. ISBN 80-860 I 0-70-8. 
was overwhelmed by the noise of the groove. It is worth mentioning that the company was involved in the recording and publishing of the speeches of the Reich Minister of Propaganda, Joseph Goebbels.

At the beginning of 1943 ESTA expanded from publishing to holding festivals, concerts, cabarets and at the same time was given authorisation to "... manufacture tools or equipment or medium to communicate, transfer, oscillate, or reproduce sound or image, especially gramophone discs, gramophones, gramophone parts, gramophone matrixes, radio, television, photograph or film parts, amplifiers, as well as organize concerts, festivals, license or carry out in commercial or business activities in the context of social purposes." 142

When the war was over, a new label with the Made in Czechoslovakia sign was added and ESTA quickly forgot about its former relationships with the Nazis, while forming strong attachments with the new establishment. Sound recordings of marches Moskva [Moscow] (matrix number 4859) and more than thirty pieces by Ukrajinský sbor písní a tanců [Ukrainian Group of Songs and Dances] (matrix numbers 4867-4900) were made already in May 1945.

The colourful history of the gramophone industry in Czechoslovakia after World War II saw a whole series of measures whose ultimate goal was to bring this politically important industry under the control of the state, or, more precisely, under the control of the Ministry of Information that was controlled by the Communists since 1945. The Czechoslovak music industry was nationalized on the basis of Decree No. 100 (that is, one of the so-called Beneš decrees) dated 24 October 1945. The administration of nationalized enterprises was put in the hands of their interim manager. Nationalized assets included all assets of companies that were on the territory of Czechoslovakia and participated in the production of vinyl records before 9 May 1945, hence the company ESTA, s. r. o., Prague, Holečkova XIV., was pursuant to Decree No. 922 of 1946 part of it. ${ }^{143}$

\section{Label Catalogue and Matrix Number}

A very important part of a recording, in our case a shellac one, is the label in the form of a paper circle in the middle of the disc, which is located on each side of it. The label has been until present used as a carrier for the communication of many important pieces of information: bibliographic data and unique identifiers. Each side of the disc contains a recording or more of them (the number depends on the size of the disc and also on the length of the recording), and each recording is connected to the name listed on the label attached. It also contains the name of the publishing label (or company), the names of the performers, the data about the speed of playback, and last but not least, the unique identifiers in the form of two numbers. Every record label has such identifiers that can distinguish between the different discs, different tracks recorded in different years or between individual companies. These identifiers are represented in the form of a number series with the addition of a letter and can be found on the paper label. These are also engraved or stamped on the inner side of the disc. It is all about the matrix number and ordering or catalogue number. Matrix numbers are always bound to the original medium, which is on the matrix plate. These numbers are located on the paper label and depicted on the inner side of the disc This number gives information about the audio recording on the given side of the disc, so two different matrix numbers can be found on one disc The catalogue numbers, on the other hand, are bound to the given recording while serving as an identifier for the entire disc. Each of these unique number identifiers is important and has its place on the label on the disc and outside, too.

142 Náš gramofon: zprávy o deskách Esta-Siemens-Polydor-Brunswick. Praha: Esta, 1942-1944.

143 GÖSSEL, Gabriel. Fonogram. 2, Výlety k počátkům historie záznamu zvuku. I. vyd. Praha: Radioservis, 2006.536 s. ISBN 80-862I 2-44-0. 


\section{ESTA Catalogues and Discs}

The only way of getting information about the gramophone records issued at the beginning of the 1930s were record company's catalogues. Every business wanting to have new records in their stores got their hands on these catalogues first, and so did the vendors that offered discs throughout the country and abroad. To give an example, we would like to present here one of the first ESTA catalogues. This catalogue covers the production from January to September 193I. In the course of the year, there were so-called additions published almost every month. These included a selection of records by various artists guided by the company's policy. As we can see in the attached catalogue (fig. I), all the information needed can be gained from it: all the artists, musical accompaniment and names of the songs or recordings. It may be noticed that two gramophone record names come under a single catalogue number. Indeed, we are still in the 1930s and the shellac discs, having the gauge of $25 \mathrm{~cm}$, managed to carry only the maximum of 3 minutes of sound.

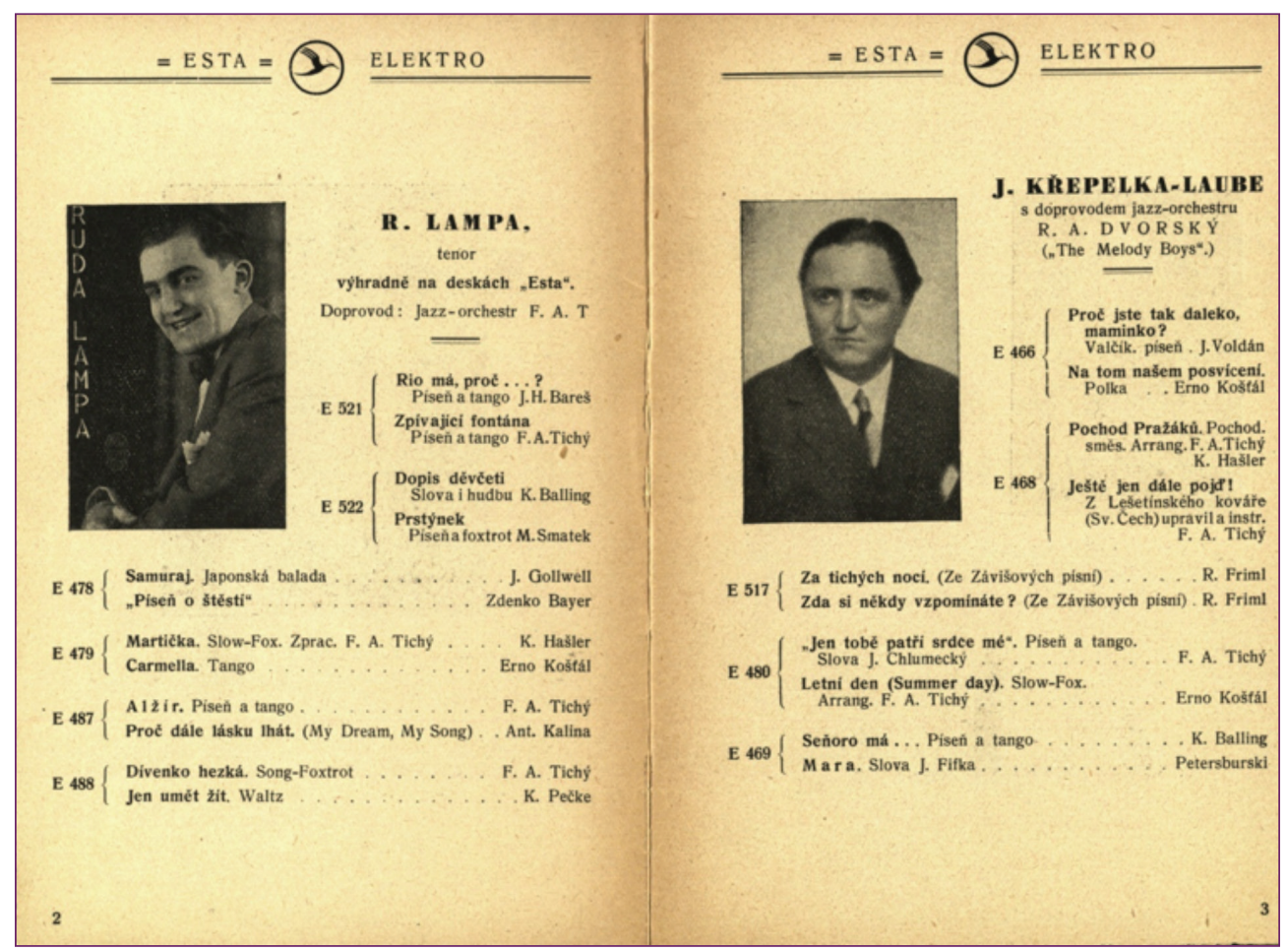

Figure I. ESTA catalogue from 1931.

Unfortunately, we are not able to get the matrix number from the catalogue itself. This number is always different for each recording and it is located in two spots at one side of the disc: stamped on the inner side and printed on the label of the recording. The next figure shows clearly the layout of all the important bibliographic information of the recordings. Each label contains the name of the company (the ESTA logo in our case). We can also see the basic information about the name of the recording: title, author or artists. The last two entries collected are the matrix and the catalogue numbers. In order to avoid possible mistakes while cataloguing numbers, we always follow "the golden rule" of the method of elimination (i.e., if we have a number stamped on the inner side of the vinyl, approximately in the first centimetre from the edge of the paper label, we can find this number on the label as well; we then know exactly what the matrix number is and the other one is thus always the catalogue number. 


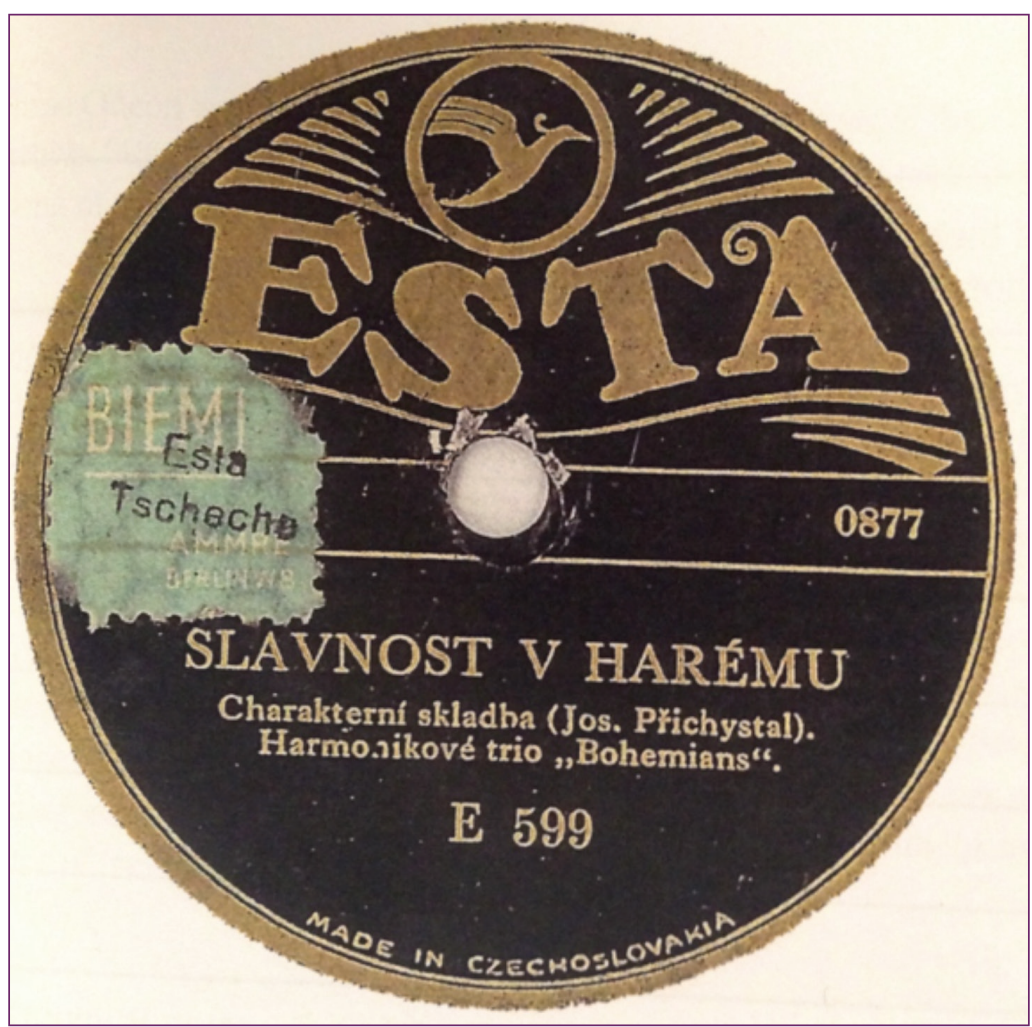

Figure 2. Label on a gramophone recording by ESTA.

One of the goals of our project is to get all the information right at all times. That is why we use the catalogues and shellac discs labels mentioned above.

\section{How to Obtain Information}

There are several ways that we use in our effort to obtain all the necessary information in order to complete the data sheets of discography of the ESTA record label and all have contributed to the results of this study. All of them have become an important part of the whole project in its own way. Without the help, willingness, and cooperation of private collectors the most important parts of this study could never be accomplished. First and foremost, we are trying to obtain information from ESTA catalogues. Such catalogues existed in different forms - from a simple sheet of paper listing a few of the most popular songs up to the carefully equipped coloured publication in hard cover. Unfortunately, these documents are not available in the collections of any of the devoted institutions, let alone digitally. The only way to gain the information is to visit private collectors who own these catalogues and who allow us to study their materials.

The most important part is to get the information about issued gramophone records and the repertoire based on them. The same was needed by the customers once the first companies started to market these records at the time. According to history, these catalogues of sound recordings already existed at a time when the music industry was still at the very beginning. The first catalogue of gramophone records was released around 1892 by the London based company Parkins and Gotto. This company was also engaged in the import business with the first Berliner's gramophones and gramophone records - more than 28 years before the first catalogues of the Czechoslovak company ESTA were published. It was necessary for every 
record company to publish catalogues of their recordings if they wanted to stay on the market at the beginning of the 20 th century. ${ }^{144}$

Due to the fact that there is no comprehensive database aimed at the activities of the ESTA company (Czech Republic has no union catalogue for audio documents), these records have to be searched for in different historical institutions. It is a serious problem since even if there are some records in an institution's collections, they are to a large extent not listed in the institution's catalogues, or the institution is not even aware of their existence. Therefore, it is necessary to visit such institutions, locate and study the records on site. In this lengthy process, we went through the selected libraries and, unfortunately, we must conclude that we are not able to go through all of the selected collections in a reasonable time frame. Among the most important institutions that we have visited we can name the National Library of the Czech Republic, the National Museum, Czech Museum of Music, and specifically the Náprstek Museum, the Moravian Library in Brno, private archive of the Supraphon company, Archive of the Czech Radio, and music library of Univerzitná knižnica in Bratislava.

\section{Making It Accessible}

The Virtual National Phonoteque of the Czech Republic has been selected for making the collected bibliographic data accessible. It is a database which serves to gain information about the existence of, storing, and medium of audio documents in selected institutions and outside them. The portal aims to fill a gap in understanding our national cultural heritage. Prior to the start of this project there was no comprehensive source of information on sound heritage there was no discography listing all relevant recordings (those published on the territory of the Czech Republic, or published abroad but relevant to the national cultural heritage), as well as no comprehensive catalogue of sound documents held by institutions in Czech territory. Thanks to the portal, we are now able to leverage other institutions to catalogue their collections of old recordings and provide their metadata records to the portal.

\section{The Portal Software}

The Virtual National Phonotheque Portal is based on VuFind open source library resource portal software. VuFind is developed and maintained by Villanova University's Falvey Memorial Library with contributors from many other institutions including the Moravian Library.VuFind utilizes Apache Solr to provide search functionality with faceted results, "More Like This" suggestions, display of deduplicated results and much more. Individual institutions can provide their metadata records via OAI-PMH or through metadata exports in MARC2I (preferred) or other formats. To manage the imported datasets and deduplicate the records the Moravian Library uses Record Manager,VuFind add-on developed by the National Library of Finland.

\section{Digitizing}

We have gathered a general overview of the audio recordings with an ESTA label in the course of the exploration carried out in memory institutions' collections. Having consulted the matter with experts in musicology and an agreement with private collectors held afterwards, we came to the conclusion that another result of our study should be a platform allowing users to listen to selected recordings. In our case this meant making a selection of an adequate number of commercially issued records (which are not available on any of the new audio media) and completing digitization in cooperation with private collectors and the Moravian Library in Brno (esp. with the help of the digitization department).

Based on new digitization standards proposed by the National Library of the Czech Republic, the Moravian Library prepared an extension of the digitization metadata standards to cover

I 44 GÖSSEL, Gabriel. Fonogram. 2, Výlety k počátkům historie záznamu zvuku. I. vyd. Praha: Radioservis, 2006. 536 s. ISBN 80-862I 2-44-0. 
digitized sound. It has also produced a gramophone record digitization recommendation describing the whole sound digitization workflow from selection to access and long term preservation, which has been certified by the Ministry of Culture earlier this year (20I4). This means a great opportunity to process selected gramophone records in high quality a make them accessible in a digital library. Czech legislation allows libraries to digitize sound documents under the condition that the library has a physical copy in their archive. ${ }^{145}$ To conform to this requirement, the Moravian Library has developed a software extension of Kramerius 4 (open source digital library system) to support access to audio documents. However, libraries need to take into account the copyright law and its interpretation of the property rights pursuant to Section 27 (the duration of property rights), which stipulates that, unless otherwise provided, the property rights remain protected for the life of the author and 70 years after his death. ${ }^{146}$ Therefore, if the recording is still protected by copyright law, the digital copy is accessible on site (in the library building) only. The library also does not allow the user to download a copy of the recording.

\section{I. Summary}

Gramophone records have been present for more than 110 years in our territory. They were the driving force at the time of the First Republic and during the second half of the 20th century became one of the most popular medium for music in the world. Despite the fact that these records where coming to the end of their life, people managed to rescue many of the records and at the present time the Czech Republic has once again become one of the most important producers of these sound recordings.

However, the attitude towards the documentation of audio documents in recent years does not correspond with this position. These sound records suffer from lack of interest; existing information is not easy to access in comprehensive databases and memory institutions themselves sometimes do not even know that something like this is present in their collections.

Our aim is to arouse interest, whether of individuals or institutions, and to attempt joint projects aimed at safeguarding and rescuing cultural heritage by preserving an image, or rather the sound, of the past.

This research is only the first step in an effort to begin to address these issues on a larger scale. However, we must not forget particularly about the actual physical condition of those carriers that we have seen during our visits in memory institutions. The problem is to be addressed by the Ministry of Culture, by adapting its view of the cultural heritage embodied in audio documents. Following the example of collegial institutions, e.g., the British Library, we need to establish a network of people who come from different institutions, study different disciplines, and are interested in this subject. Then, we need to begin to work on the issues. To start with, we could try to create a group of experts under the auspices of the National Phonotheque.

The opportunity to work with experts and especially benefit from cooperation with the private collectors was the cornerstone of our work throughout the project. Gradually, we managed to assemble complete, mainly corrected discography data of the ESTA record label. Unfortunately, we found out that physical carriers themselves are almost certainly not present in memory institutions located in the Czech Republic. This work, this survey enabled us to gather the necessary information and contacts. We will try to continue working on a general catalogue of Czech recordings in the future. All these steps should lead to increasing support and interest in our cultural heritage.

I 45 ČESKO. Zákon ze dne 29. června 200 I o knihovnách a podmínkách provozování veřejných knihovnických a informačních služeb (knihovní zákon). In: Sbírka zákonů České republiky. 200 I, částka 98, s. 5683-5688. [cit. 20 I309-06]. Dostupné z WWW: http://knihovnam.nkp.cz/sekce.php3?page=03_Leg/0 I_LegPod/Zakon257.htm.

I 46 ČESKO. Zákon č. 120 ze dne 7. dubna 2000 o právu autorském, o právech souvisejících s právem autorským a o změně některých zákonů (autorský zákon). In: Sbírka zákonů České republiky. 2000, částka 36, s. I 658- I 685. ISSN | 2 I | - | 244. Dostupné z WWW: http://www.osa.cz/media/90809/(autorsk_375\%20z_34 I kon).pdf. 


\section{I2. Bibliography}

Až kometa šlehne nás: z historie zvukového záznamu. Praha: Galery, 2003. 9 I s. ISBN 8086010-70-8.

Celkový katalog gramofonových desek: Supraphon, Ultraphon, Esta.V Praze: Gramofonové závody, 1948. I sv. (přeruš. str.).

České muzeum hudby on-line katalog [online databáze]. Praha: Národní muzem. České muzeum hudby, [20I4-] . Dostupná z: http://opac.nm.cz:8080/opaccmh/

ČESKO. Zákon ze dne 29. června 200 I o knihovnách a podmínkách provozování veřejných knihovnických a informačních služeb (knihovní zákon). In: Sbírka zákonů České republiky. 200I, částka 98, s. 5683-5688. [cit. 2013-09-06]. Dostupné zWWW: http:// knihovnam.nkp.cz/sekce.php3?page=03_Leg/0I_LegPod/Zakon257.htm

ČESKO. Zákon č. 120 ze dne 7. dubna 2000 o právu autorském, o právech souvisejících s právem autorským a o změně některých zákonů (autorský zákon). In: Sbírka zákonů České republiky. 2000, částka 36, s. I658-1685. ISSN I 2 I I-I244. Dostupné zWWW: http://www.osa.cz/media/90809/(autorsk_375\%20z_34I kon).pdf

Československá hudba na gramofonových deskách: Ultraphon, Esta, Supraphon.Vyd. I. Praha: Gramofonové závody, 1947.6I s.

GÖSSEL, Gabriel. Fonogram. 2,Výlety k počátkům historie záznamu zvuku. I. vyd. Praha: Radioservis, 2006. 536 s. ISBN 80-862। 2-44-0.

GÖSSEL, Gabriel. Fonogram. 2,Výlety k počátkům historie záznamu zvuku. I. vyd. Praha: Radioservis, 2006. 536 s. ISBN 80-862I 2-44-0.

Gramotechnika: první oficielní odborný list Svazu pro průmysl a obchod s gramofony v ČSR. Praha: Svaz průmyslu a obchodu gramofony, hudebními nástroji a jich př́slušenstvím, 1929-1935

Náš gramofon: zprávy o deskách Esta-Siemens-Polydor-Brunswick. Praha: Esta, 1942-1944.

NKC: Online katalog Národní knihovny České republiky [online databáze]. Praha: Národní knihovna České republiky, 2009- . Dostupná z: http://aleph.nkp.cz/F/DRP95MP9R 68B2RGRUNT23PH2JMG8J8SX3R8YD83KRJ528DVCIH-36I6I ?func=file\&file name $=$ find-b\&local_base $=$ NKC

SKC: Souborný katalog České republiky (CASLIN) [online databáze]. Praha: Národní knihovna Ceské republiky, 2009- . Dostupná z: http://aleph.nkp.cz/F/GSKUBINVI597AV 99AEC4P8PIUIQRQRHASMIFK6EPJJBG2CJIFL-03030?func=file\&file_name=findb\&local_base $=$ SKC 